\title{
Afferents to the Midline Thalamus Issue Collaterals to the Nucleus Tractus Solitarii: An Anatomical Basis for Thalamic and Visceral Reflex Integration
}

\author{
Kazuyoshi Otake, ${ }^{1}$ Donald J. Reis, ${ }^{1}$ and David A. Ruggiero', ${ }^{1,2}$ \\ 'Laboratory of Neurobiology, Department of Neurology and Neuroscience, Cornell University Medical College, New York, \\ New York 10021 and ${ }^{2}$ Neurological Research Institute of Lubec, Lubec, Maine 04652
}

The goal of this study was to establish a structural basis for thalamic and visceral integration. We sought to define neural networks that convey visceral or integrated environmental stimuli to the diffuse thalamocortical relay system and that link periodic changes in forebrain and visceral reflex function. Our experiments were designed to determine whether afferents to the midline-intralaminar thalamic nuclei (MIT) issue collaterals to the general viscerosensory division of the nucleus tractus solitarii (NTS). Experiments were performed on anesthetized male Sprague-Dawley rats. Two tracers, FluoroGold and rhodamine latex microbeads, were stereotaxically centered on the MIT and NTS, respectively, in each animal. Subsets of midline thalamic afferents were identified that issue collaterals to the solitary complex. In the cerebral cortex, dually labeled soma were detected in layer $\mathbf{V}$ of the insular and infralimbic areas. In the subcortical forebrain, the lateral septal nucleus, anterolateral area of the bed nuclei of stria terminalis, medial preoptic nucleus, medial and central amygdaloid nuclei, caudal lateral hypothalamic area, supramammillary nucleus, and parvicellular division of the paraventricular hypothalamic nucleus constitute other newly identified sources of collateral projection. In the midbrain and pons, collateral projection cells were observed in the periaqueductal gray, dorsal raphe nucleus, mesencephalic reticular formation, laterodorsal tegmental nucleus, lateral and medial parabrachial nuclei, and noradrenergic A5 area. In the lateral parabrachial nucleus, dually labeled neurons were detected in the dorsal-lateral division. In the medulla, collaterals are derived from cells in the rostral and caudal ventrolateral reticular formation and parapyramidal area. Dually labeled cells were also found in the cerebellar fastigial nucleus. Collaterals may coordinate changes in visceral reflex excitability and thalamocortical rhythms during phases of sleep-wake cycle and behavioral expression.

IKey words: midline-intralaminar thalamic nuclei, diffuse thalamocortical projection system, nucleus tractus solitarii,

\footnotetext{
Received Jan. 18, 1994; revised Mar. 10, 1994; accepted Mar. 24, 1994.

This work was supported by HL18974 (D.J.R., D.A.R.) and NS28200 (D.A.R.). We thank Mr. Muhammad Anwar for his expert technical assistance and $\mathrm{Mr}$. Terence Ziegler for the excellent photography. K.O. is on leave from the Department of Anatomy, Faculty of Medicine, Tokyo Medical and Dental University,

Tokyo, Japan, and is partly supported by the Japan Ministry of Education, Science and Culture.

Correspondence should be addressed to Dr. David A. Ruggiero, Division of Neurobiology, Cornell University Medical College, 411 East 69th Street, New York, NY 10021

Copyright (C) 1994 Society for Neuroscience $0270-6474 / 94 / 145694-14 \$ 05.00 / 0$
}

autonomic function, collaterals, double retrograde transport study, rat]

Homeostasis is maintained by processing multimodal afferents to form integrated patterns of autonomic response appropriate to the physiological state of the organism. Examples include modifications of cerebral electrocortical activity and cardiorespiratory reflex function that accompany severe muscular exercise, the defense-arousal response, or phases of the sleep-wake cycle (for reviews, see Jordan, 1990; Parmeggani and Morrison, 1990).

A link between the state of vigilance or wakefulness and autonomic function was observed by Jackson and Stewart (1899) in patients with epileptic automatisms associated with lesions of the uncinate region. Intimate associations between the level of arousal and activity of the autonomic nervous system are well documented, clinically and experimentally, in human and animal models. As reviewed by Pickering (1990), the contrasting effects of sleep and wakefulness on blood pressure are reflected by the progressive falls coinciding with stages 3 and 4 of deep slow wave sleep or the sympathetic vasoconstriction and elevations during periods of arousal of stages 1 and 2 and on waking.

The neural networks that link recurring periodic changes in cerebral cortical activity and visceral reflex function have not been identified. It has long been recognized that the electrical activity of the cerebral cortex during sleep, arousal, pain perception, and selective attention, and even consciousness itself is regulated by multimodal stimuli conveyed by way of afferents terminating in the diffuse or midline-intralaminar thalamus (MIT) (for reviews, see Plum and Posner, 1980; Herkenham, 1986; Jones, 1989). Unlike the specific or discriminative thalamosensory relay nuclei concerned with relaying epicritical sense, neurons in the diffuse system, in toto, project globally across the cortical mantle and striatum (Berendse and Groenewegen, 1991) and elicit widespread cortical recruiting responses originating in the thalamic reticular nucleus (Purpura, 1970; Yingling and Skinner, 1976; Steriade and Llinás, 1988; Steriade et al., 1990).

We speculate, based in part on axonal transport data, that neurons may exist that coordinate diffuse thalamocortical sensory processing, for example, modulation of cortical activity during phases of the sleep-wake cycle, and visceral reflex function. In support, subsets of thalamic afferents implicated in state-dependent alterations of electrocortical activity (Asanuma, 1992; Otake et al., 1993) derive from brainstem nuclei, notably, within the mesopontine tegmentum, recently identified as novel 


\section{OR 2}
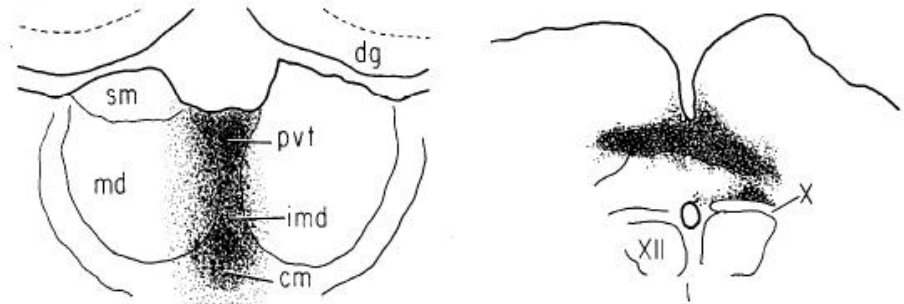

OR 4
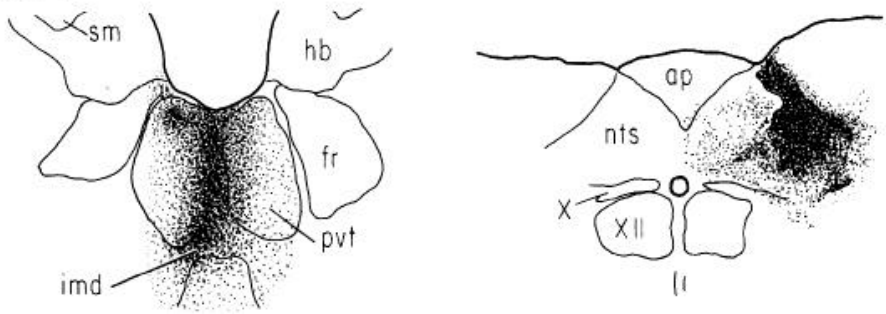

OR 5
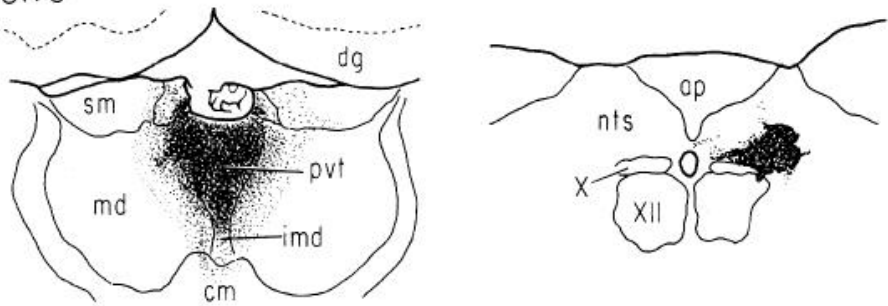

OR 6
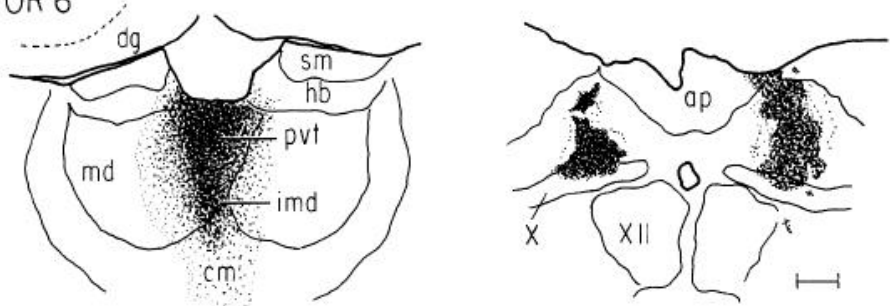

Figure 1. Camera lucida drawings of injections of FluoroGold in the midline thalamus (left column) and of rhodamine-microbeads in the nucleus tractus solitarii (NTS) (right column). In each case, the FluoroGold deposit is concentrated in the paraventricular thalamic nucleus and also encompassed the intermediodorsal, central medial, and mediodorsal nuclei. Approximate distances from bregma defined in the atlas by Paxinos and Watson (1986) are $-2.30 \mathrm{~mm}(O R 2),-3.60 \mathrm{~mm}(O R 4)$, $-2.12 \mathrm{~mm}($ OR5), and $-2.80 \mathrm{~mm}$ (OR6). The injection site in the NTS is centered on the commissural (case OR2) or medial (cases OR4, OR5, OR6) subnucleus and variably involves the dorsal part of the dorsal motor nucleus of the vagus. See Appendix for abbreviations used in figures. Scale bar: $500 \mu \mathrm{m}$ for left column, $250 \mu \mathrm{m}$ for right column.

sources of afferent projection to the nucleus tractus solitarii (NTS), first-order recipient of primary visceral afferents (Ruggiero et al., 1994), or an area of the rostral ventrolateral medulla involved in visceral reflex control (Yasui et al., 1990). Comparisons of other projection nuclei also predict additional probable sources of shared afferents, including regions identified as members of ascending cortical activating systems (Starzl and Magoun, 1951; Shute and Lewis, 1967; Vincent et al., 1986; Jones and Cuello, 1989). Dual labeling studies, however, have yet to confirm the existence of these hypothesized projection neurons.

The present study was therefore designed to determine wheth-
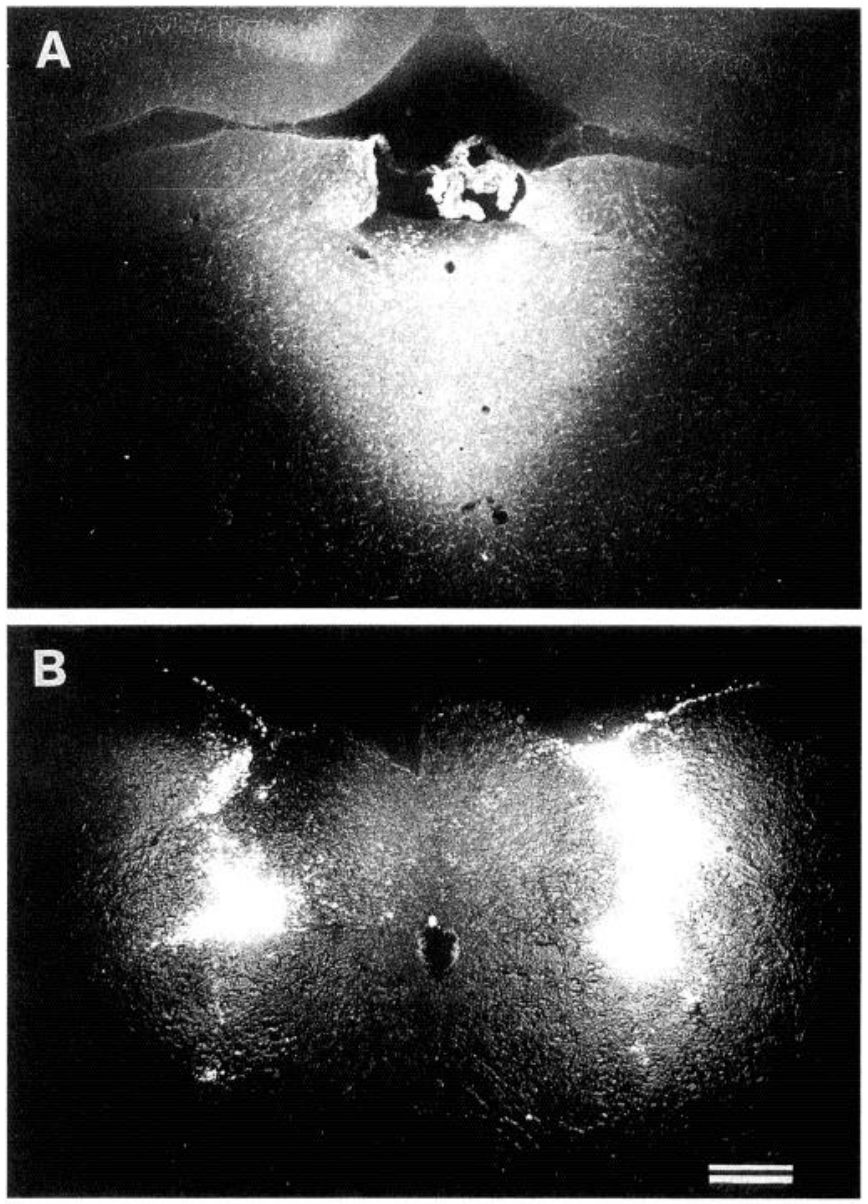

Figure 2. Photomicrographs demonstrate representative injection sites. FluoroGold was injected into the midline thalamus $(A$, case OR5) and rhodamine-microbeads into the nucleus tractus solitarii (NTS) ( $B$, case OR6). Scale bar: $500 \mu \mathrm{m}$ for $A, 250 \mu \mathrm{m}$ for $B$.

er neurons in the CNS issue collaterals to cells engaged in diffuse thalamocortical sensory processing by the midline thalamus and viscerosensory reflex integration by the NTS.

A preliminary report of these observations was presented at the 23rd annual meeting of the Society for Neuroscience (Otake et al., 1993).

\section{Materials and Methods}

Data were obtained from four male Sprague-Dawley rats (200-250 gm) anesthetized with halothane (induced at $4 \%$ and maintained at $2 \%$ in $100 \% \mathrm{O}_{2}$ ). Two fluorescent tracers, FluoroGold (FG; $2 \%$ in distilled water; Fluorochrome Inc.) or rhodamine-impregnated latex microbeads ( $\mathrm{R}-\mathrm{Mb} ; 50 \%$ in distilled water; Luma-Fluor Inc.), were used for dual retrograde-labeling experiments. Under sterile conditions, the sagittal sinus was exposed by perforating, with a dental drill, parietal bone along the sagittal suture, extending $2-3.5 \mathrm{~mm}$ caudal to bregma. The dural membranes were cut and reflected, and FG was injected stereotaxically into the paraventricular and intermediodorsal nuclei of the thalamus with a glass micropipette attached to a syringe. Axial muscles of the neck were next cut and reflected and an occipital craniotomy made to expose the posterior fossa. The dura were cut and reflected and the dorsum of the medulla exposed. The micropipette was inserted into stereotaxically defined loci in the NTS by using obex as stereotaxic zero. Thereafter, injections of $\mathrm{R}-\mathrm{Mb}$ were made at the level of the obex or $0.5 \mathrm{~mm}$ caudally, at the calamus scriptorius. A total volume of $100 \mathrm{nl}$ of each tracer was injected over $10 \mathrm{~min}$. The micropipettes were left in situ for 20-30 min following each injection. Bone wax was applied and the tissues sutured. After a survival period of 5-7 d, the animals were 

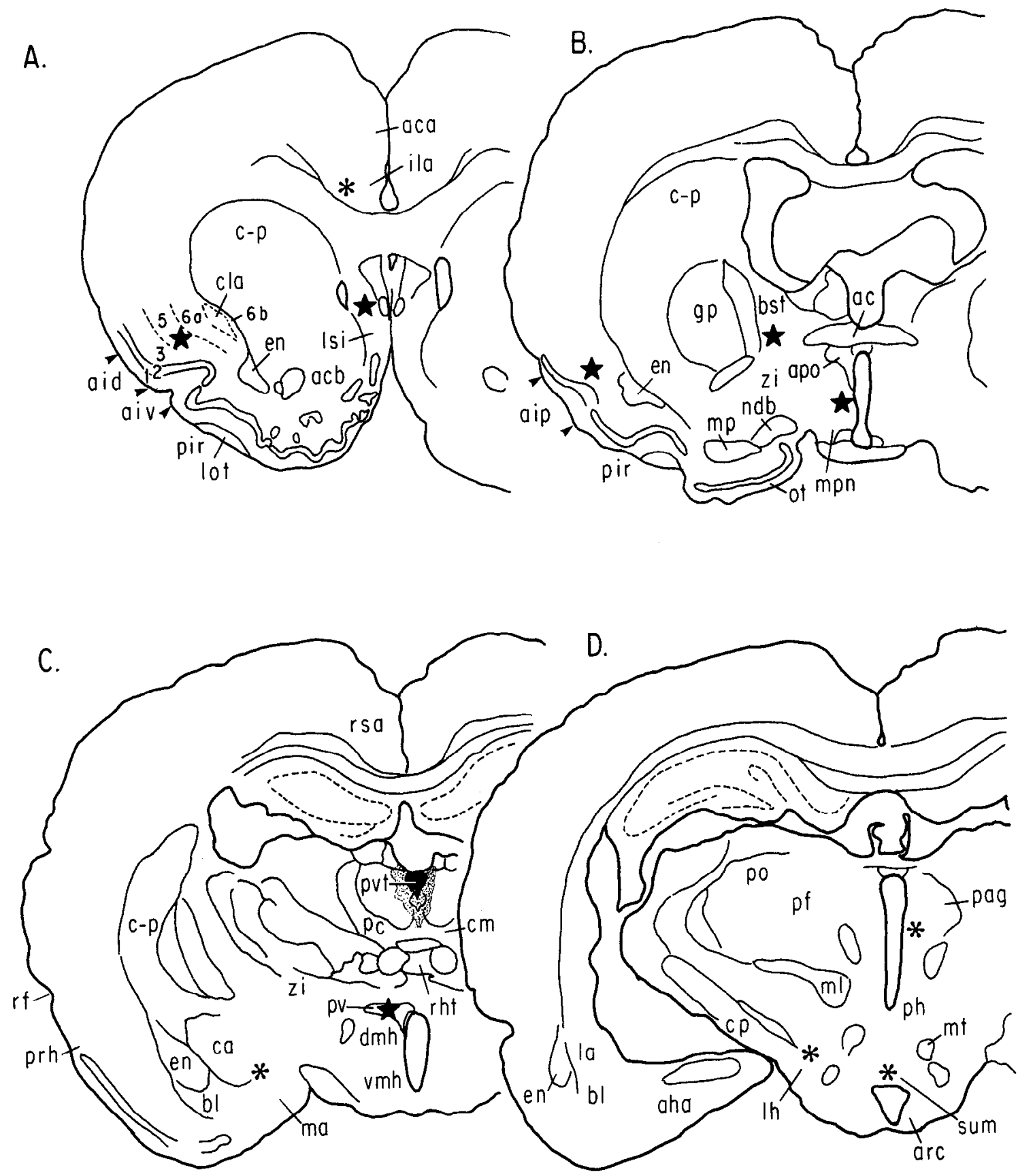

Figure 3. Diagrams summarize the locations in transverse sections of dually labeled cell bodies in the forebrain. The thalamic injection site is located in the plane depicted in C. Stars or asterisks indicate areas where dually labeled cells were observed. Areas marked with stars were photographed (Figs. 4-7); areas designated with asterisks are discussed in text.

deeply anesthetized with sodium pentobarbital $(90-100 \mathrm{mg} / \mathrm{kg}$, i.p.) and perfused transcardially with physiological saline followed by $4 \%$ paraformaldehyde in $0.1 \mathrm{M}$ phosphate buffer. Tissues were sectioned in the transverse plane at a $35 \mu \mathrm{m}$ thickness on a freezing microtome, mounted on gelatin-coated slides, and air dried. The sections were examined for single- or dual-labeled cell bodies with an epifluorescent microscope (Nikon FX) at appropriate wavelengths and photographed on Kodak TMAX 400 ASA film.

\section{Results}

Injection sites

Injection sites are shown in Figures 1 and 2. In each animal, the FG deposit was centered in the paraventricular thalamic nucleus with some spread to adjacent structures including me- diodorsal, intermediodorsal, and central medial nuclei (Figs. 1, $2 A$ ). Bilateral or unilateral deposits of $\mathrm{R}-\mathrm{Mb}$ within the medial and/or commissural subnuclei of the NTS are shown in Figures 1 and $2 B$. In all cases, deposits of R-Mb were associated with variable spread to the subjacent dorsal motor nucleus of the vagus or nucleus parasolitarius.

FG-labeled cells were found in areas reported in a concomitant retrograde transport study of the midline thalamus (Otake et al., 1993). The patterns of retrograde transport of R-Mb were comparable to previously defined origins of NTS afferents (Ross et al., 1981; van der Kooy et al., 1984; Ruggiero et al., 1987, 1994).

Our objectives were to determine whether neurons exist that 

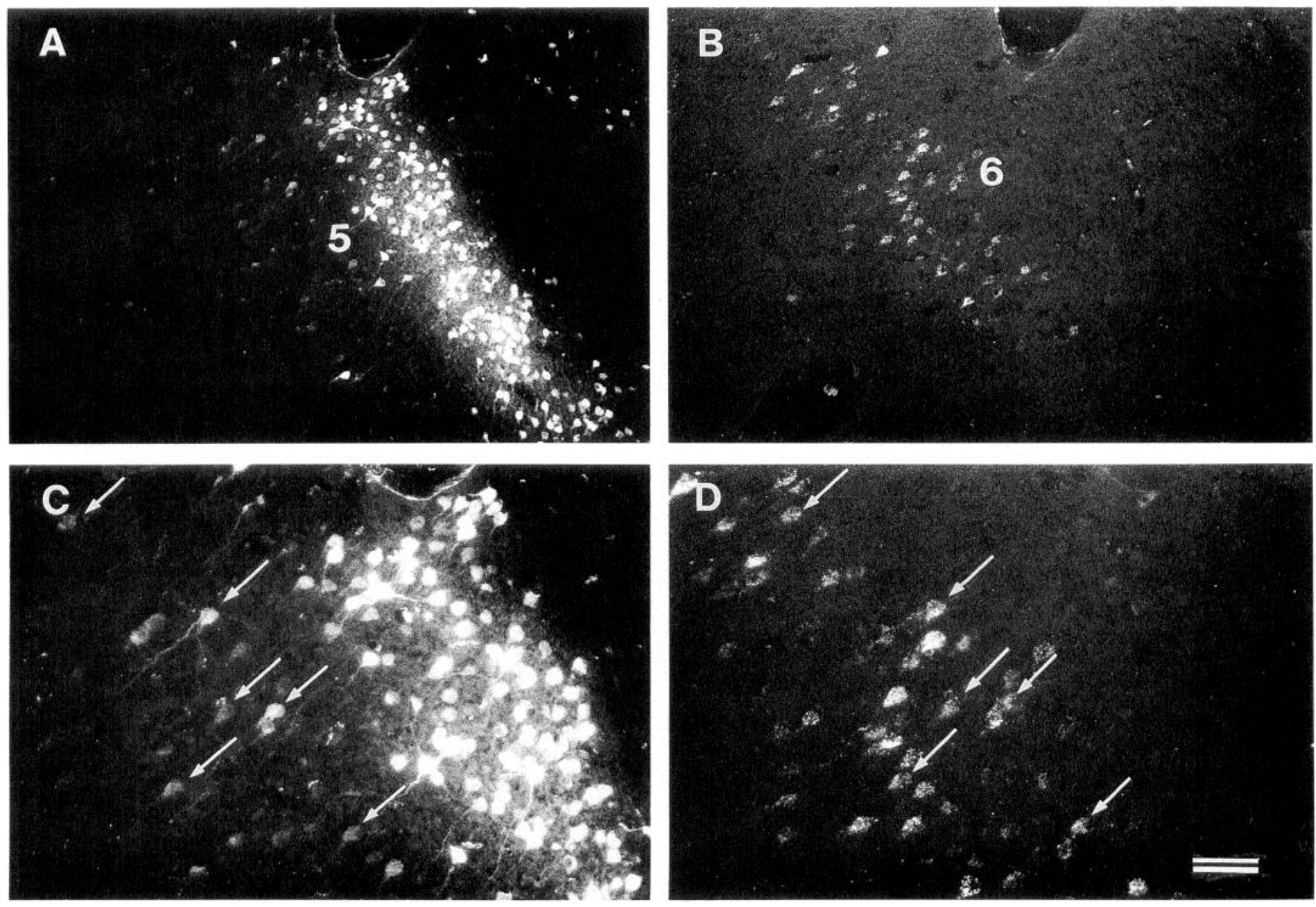

Figure 4. Photomicrographs of retrogradely labeled cells in the insular cortex from injections of FG into the thalamus $(A, C)$ and R-Mb into the NTS $(B, D)$. Note that the thalamic afferents are principally derived from lamina VI and NTS afferents exclusively from lamina V. Dually labeled cells were observed in lamina $\mathrm{V}$ and are indicated with arrows in higher-power photomicrographs $(C, D)$. Data from case OR6. Scale bar: $100 \mu \mathrm{m}$ for $A$ and $B, 50 \mu \mathrm{m}$ for $C$ and $D$.

issue collaterals to the MIT and the NTS. Although the majority of thalamic and medullary afferents were spatially segregated, dually labeled soma were detected at every level of the brain. The locations of collateral projection cells are summarized in Figure 3 for the forebrain and in Figure 8 for the midbrain and hindbrain.

\section{Cerebral cortex}

In the cerebral cortex, dually labeled cells were found in insular, infralimbic, and prelimbic cortices. In the insular cortex (Fig. 4), cells were retrogradely labeled from the midline thalamus in laminae VI and V (Fig. $4 A, C$ ). In lamina V, dually labeled cells were backfilled from the MIT and the NTS (Fig. $4 B, D$ ). Dually labeled cells were also found in lamina $\mathrm{V}$ of infra- and prelimbic cortical areas.

\section{Subcortical forebrain}

In the bed nuclei of the stria terminalis, dually labeled cell bodies were found in the anterolateral area (Fig. 5), as defined by the nomenclature of Ju and Swanson (1989). In comparison to the numbers of NTS-afferent projection neurons in the cerebral cortex and bed nuclei of the stria terminalis, those labeled in the preoptic and septal nuclei were sparse. However, double-labeled cells were clearly detected in the medial preoptic area (Fig. 6A,B) and the lateral septal nucleus (Fig. $6 C, D$ ). In the retrochiasmatic nucleus, cells were clearly dually labeled, albeit lightly, for both tracers. In the amygdala, central and medial amygdaloid subnuclei contained small number of dually labeled cell bodies. These dually labeled cells extended into the adjacent substantia innominata.

Afferents to the NTS and MIT were also labeled in the lateral hypothalamic area and organized topographically: cells of origin of thalamic afferents were skewed medially to those labeled from the NTS. Dually labeled cells in the lateral hypothalamus were detected along the border between these two territories. Supramammillary and arcuate nuclei revealed double-labeled cells although these cell groups were lightly labeled. The paraventricular hypothalamic nucleus (Fig. 7) showed a segregation of the two afferent populations. NTS afferents were heavily concentrated in the parvicellular division of the paraventricular hypothalamic nucleus (Fig. $7 B, D$ ); prethalamic afferents were sparsely labeled (Fig. 7A,C). An example of a double-labeled cell is shown in the photomicrographs of Figure 7, $C$ and $D$.

\section{Midbrain}

In the periaqueductal gray, a small number of dually labeled cells was observed. Labeled cells were also found in the dorsal raphe nucleus (Fig. 9A,B), nucleus raphe magnus, substantia 

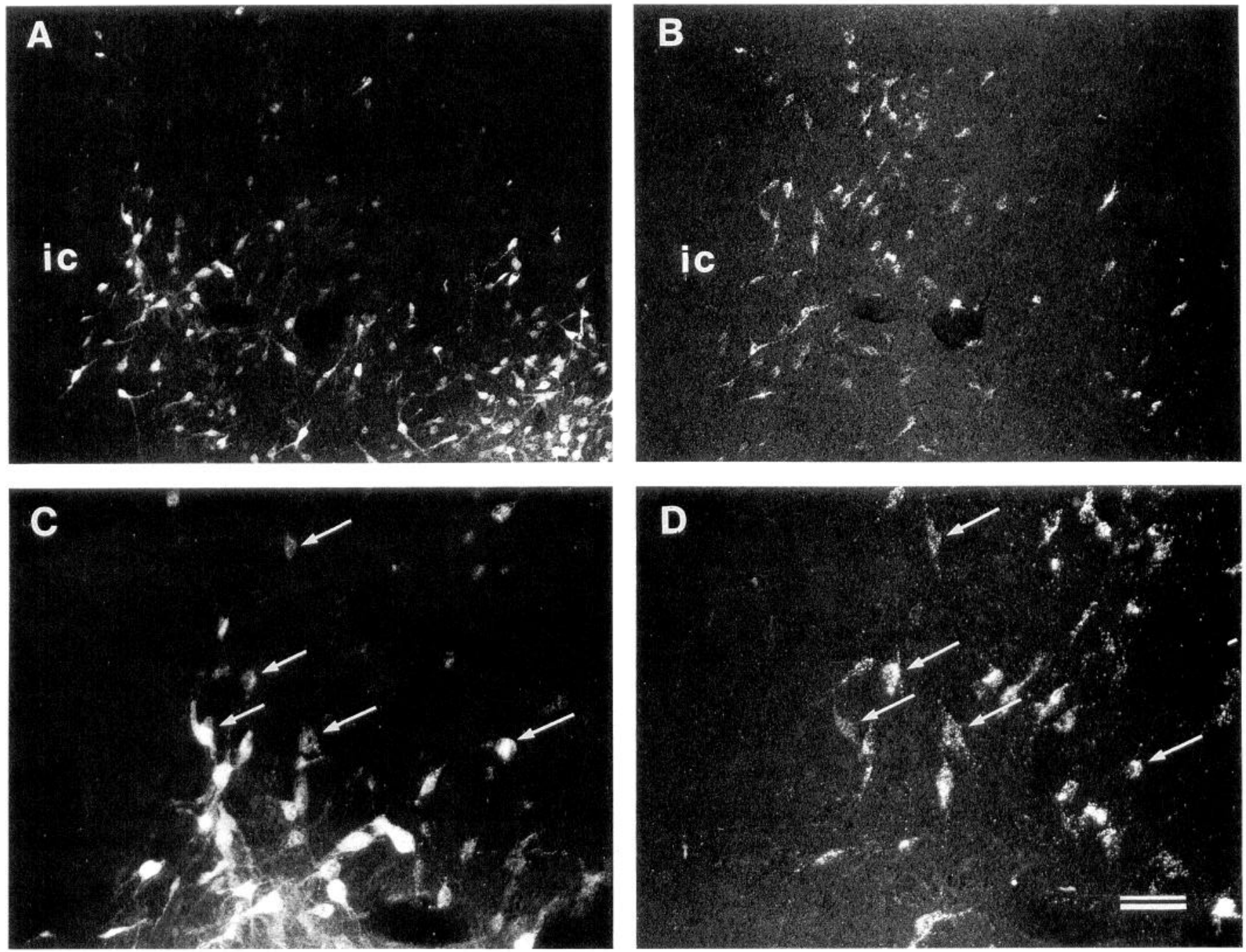

Figure 5. Photomicrographs of retrogradely labeled cells in the bed nuclei of the stria terminalis from injections of the tracers FG and R-Mb into the thalamus $(A, C)$ and NTS $(B, D)$, respectively. Afferents to both regions were derived mainly from the anterolateral area of the bed nuclei (Ju and Swanson, 1989), adjacent to the internal capsule (ic). Thalamic afferents were skewed ventrally and NTS afferents, dorsally. Dually labeled cells are indicated with arrows in higher-power photomicrographs below $(C, D)$. Data from case OR4. Scale bar: $100 \mu \mathrm{m}$ for $A$ and $B ; 50 \mu \mathrm{m}$ for $C$ and $D$.

nigra pars compacta, and mesencephalic reticular formation (Fig. $9 C, D)$.

\section{Cerebellum}

In the fastigial nucleus, dually labeled cells were detected at intermediate levels of the nucleus within its dorsolateral division (Fig. 9E,F). Other areas of the cerebellum were unlabeled.

\section{Pons}

In the pons, dually labeled cells were located in lateral and medial parabrachial nuclei. In the lateral parabrachial nucleus (Fig. 10A,B) most dually labeled cells were detected along a circumscribed lamina constituting the dorsal-lateral division. The laterodorsal tegmental nucleus (Fig. 10C,D) and A5 area (Fig. $10 E, F$ ) were other sites containing double-labeled cell bodies.

\section{Medulla}

In the medulla, collateral projection cells were labeled in the rostral ventrolateral reticular formation at a level immediately caudal to the facial nucleus (Fig. $11 A, B$ ). Double-labeled cells were also observed in the retroambigual area of the lateral tegmental field at the level of obex (Fig. $11 C, D$ ). Collateral projection neurons were also detected in the parapyramidal area contiguous with the nucleus raphe magnus (Fig. $11 E, F$ ). No dually labeled cells were observed in the medullary raphe pallidus or obscurus.

\section{Discussion}

This study demonstrates for the first time that each major division of the brain issues collaterals to the nondiscriminative sensory thalamus and the general visceral afferent division of the solitary nuclear complex. Dual retrograde tracing data provide strong evidence that nuclei engaged in diffuse thalamic relay function and viscerosensory processing are structurally and thus functionally integrated by shared afferents.

\section{Methodological considerations}

The specificity of our retrograde transport findings is supported by two observations. (1) The overall distributions of identified afferents were comparable to data obtained in previous retrograde tracer studies of the NTS and/or dorsal motor nucleus of 

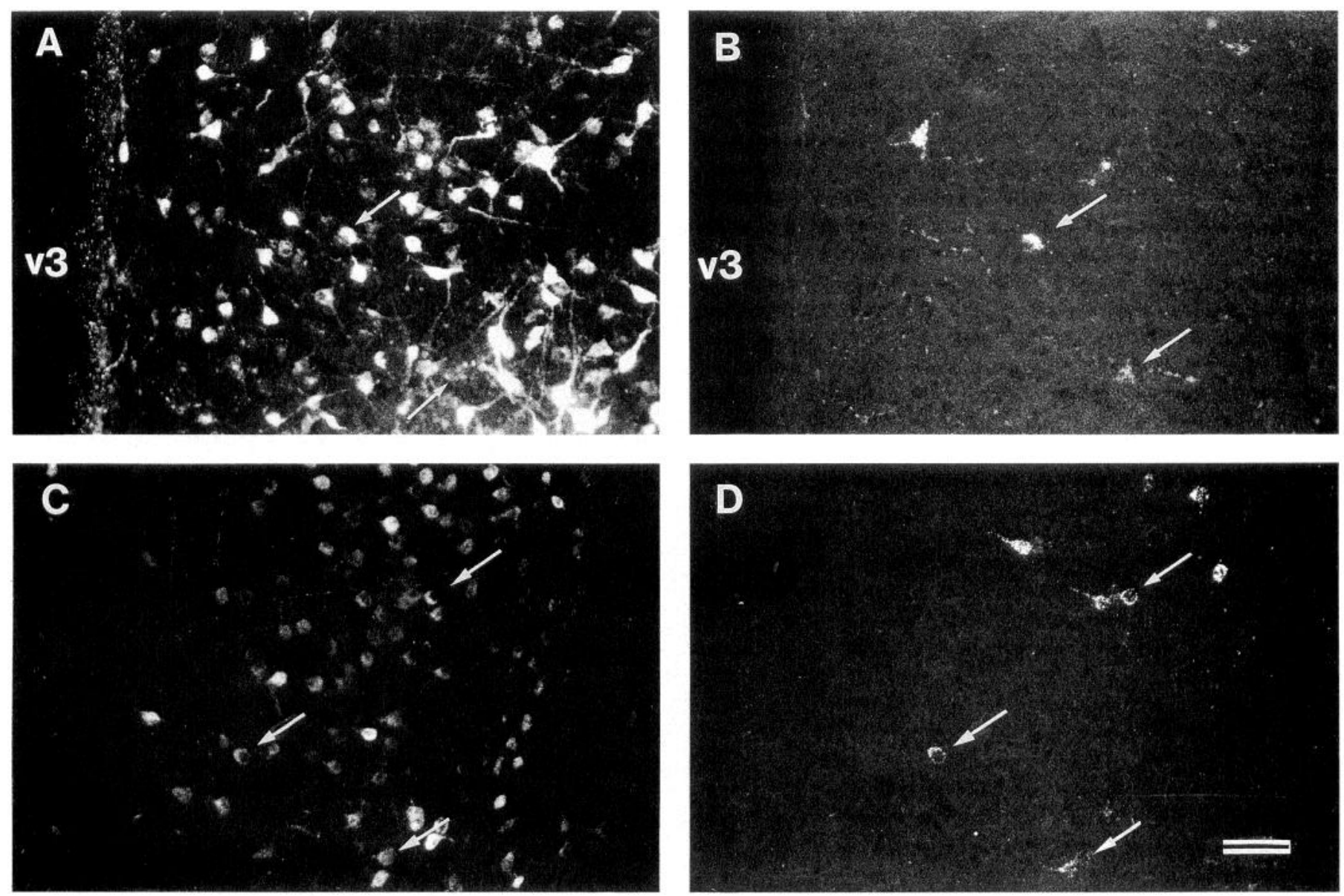

Figure 6. Photomicrographs of retrogradely labeled cells in the medial preoptic $(A, B)$ and lateral septal nuclei $(C, D)$ from injection of the tracers into the thalamus (left column) and NTS (right column). Dually labeled cells are indicated with arrows. v3, third ventricle. Data from case OR4. Scale bar, $50 \mu \mathrm{m}$.

the vagus (Ross et al., 1981; ter Horst et al., 1984; van der Kooy et al., 1984; Ruggiero et al., 1987, 1994) or the MIT (Cornwall and Phillipson, 1988; Otake et al., 1993). Based on our work, labeling patterns obtained with fluorescent dyes were identical to retrograde transport of wheat germ agglutinin-horseradish peroxidase or cholera toxin B subunit from similarly placed injection deposits (Otake et al., 1993). (2) Several of the identified sources of afferent projection have been confirmed with anterograde tracers as terminating in the NTS or MIT (e.g., Hopkins and Holstege, 1978; Ricardo and Koh, 1978; Saper et al., 1979; Saper and Loewy, 1980; Berk and Finkelstein, 1982; Eberhart et al., 1985; Holstege et al., 1985; Jones and Yang, 1985; Luiten et al., 1985; Ruggiero et al., 1987; Sesack et al., 1989).

Our injection sites encompassed several subnuclei of the dorsal midline thalamus including the paraventricular thalamic nucleus. Until recently, the status of this prominent subnucleus was controversial, based on developmental studies and in particular because of the absence of an identified projection upon the cerebral cortex (see Jones, 1985, for review). Berendse and Groenewegen (1991), however, have convincingly demonstrated with the anterograde tracer Phaseolus vulgaris leucoagglutinin, cortical projections, for example, onto insular and infralimbic prefrontal cortices, complementing those of other members of the midline-intralaminar complex. These observations have subsequently been confirmed and extended by K. Otake, M. Anwar, and D. A. Ruggiero (unpublished observations).
Our medullary injection deposits, although centered on the NTS, also encompassed portions of the dorsal motor nucleus of the vagus. Both subnuclei constitute members of the solitary nuclear complex (NTS-X). Branches of afferents terminating in the NTS may, therefore, also terminate within the dorsal motor nucleus of the vagus. Primary visceral afferents as well as certain centrally derived projections to the NTS form synapses on or closely invest parasympathetic motoneurons of the dorsal motor nucleus of the vagus (Loewy and Spyer, 1990). It is well established that dendrites of parasympathetic preganglionic motoneurons in the subnucleus gelatinosus of the NTS are targets of first-order gastric afferents, implicated in vagovagal mechanoreceptor reflexes (Rinaman et al., 1989). These observations suggest that retrograde tracer deposits, even if confined to the NTS, could potentially be incorporated by afferents targeting dendrites of preganglionic motoneurons.

The goal of our study was to identify specifically cell groups that issue collaterals to the NTS-X and MIT. Since other nuclei in the forebrain and lower brainstem share similar sources of afferent input, the identified cells may branch more extensively than revealed by dual-labeling studies. The reticular formation of the lateral tegmental field deep to the NTS-X, for example, is supplied by afferents derived from several of the same cell groups backfilled from the NTS or the dorsal motor nucleus of the vagus (Ross et al., 1981; Schwaber et al., 1982; van der Kooy et al., 1984; Ruggiero et al., 1987, 1989). 

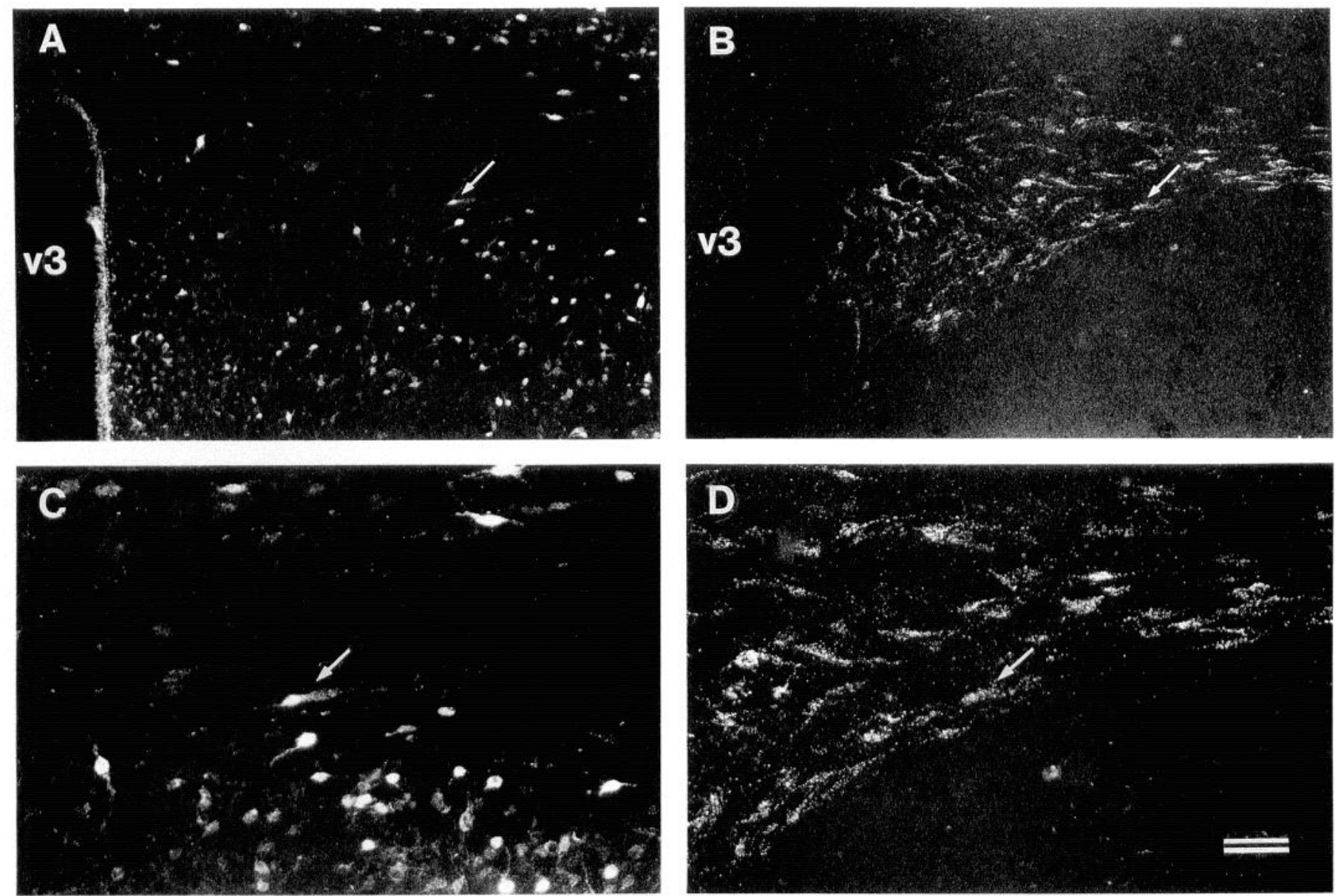

Figure 7. Photomicrographs of retrogradely labeled cells in the paraventricular hypothalamic nucleus from injections of FG and R-Mb into the thalamus $(A, C)$ and NTS $(B, D)$, respectively. Note the sparse labeling of thalamic afferents, compared to the dense transport from the NTS. A dually labeled cell at the marginal zone of the nucleus is indicated with arrows in the low- $(A, B)$ and high-power photomicrographs $(C, D)$. Data from case OR5. Scale bar: $100 \mu \mathrm{m}$ for $A$ and $B, 50 \mu \mathrm{m}$ for $C$ and $D$.

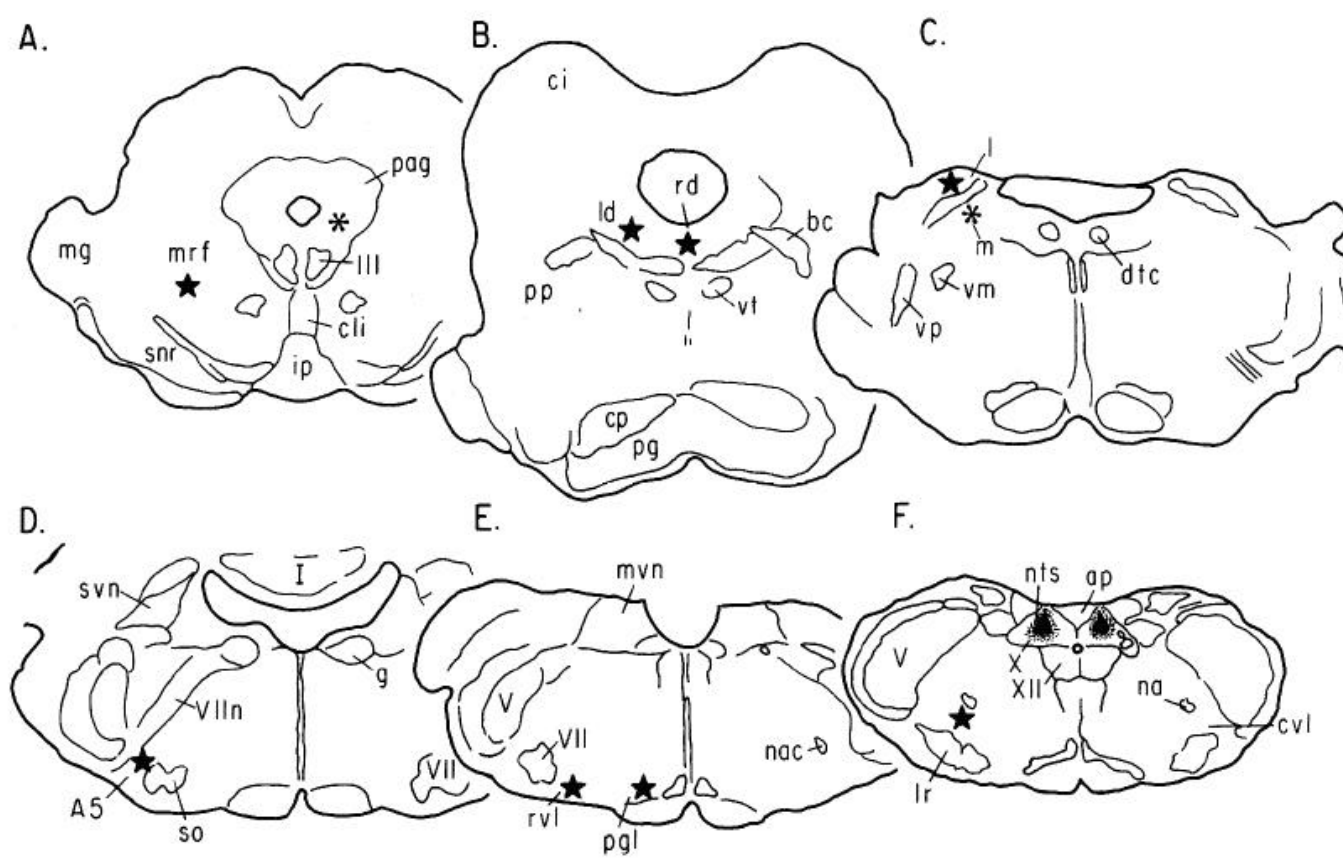

Figure 8. Diagrams summarize the locations in transverse sections of dually labeled cell bodies in the midbrain and hindbrain. The NTS injection site is located in plane $F$. Stars or asterisks indicate areas where dually labeled cells were observed. The areas marked with stars appear in the photomicrographs of Figures 9-11. Transport to areas indicated by asterisks are discussed in text. Cerebellum is not illustrated. 

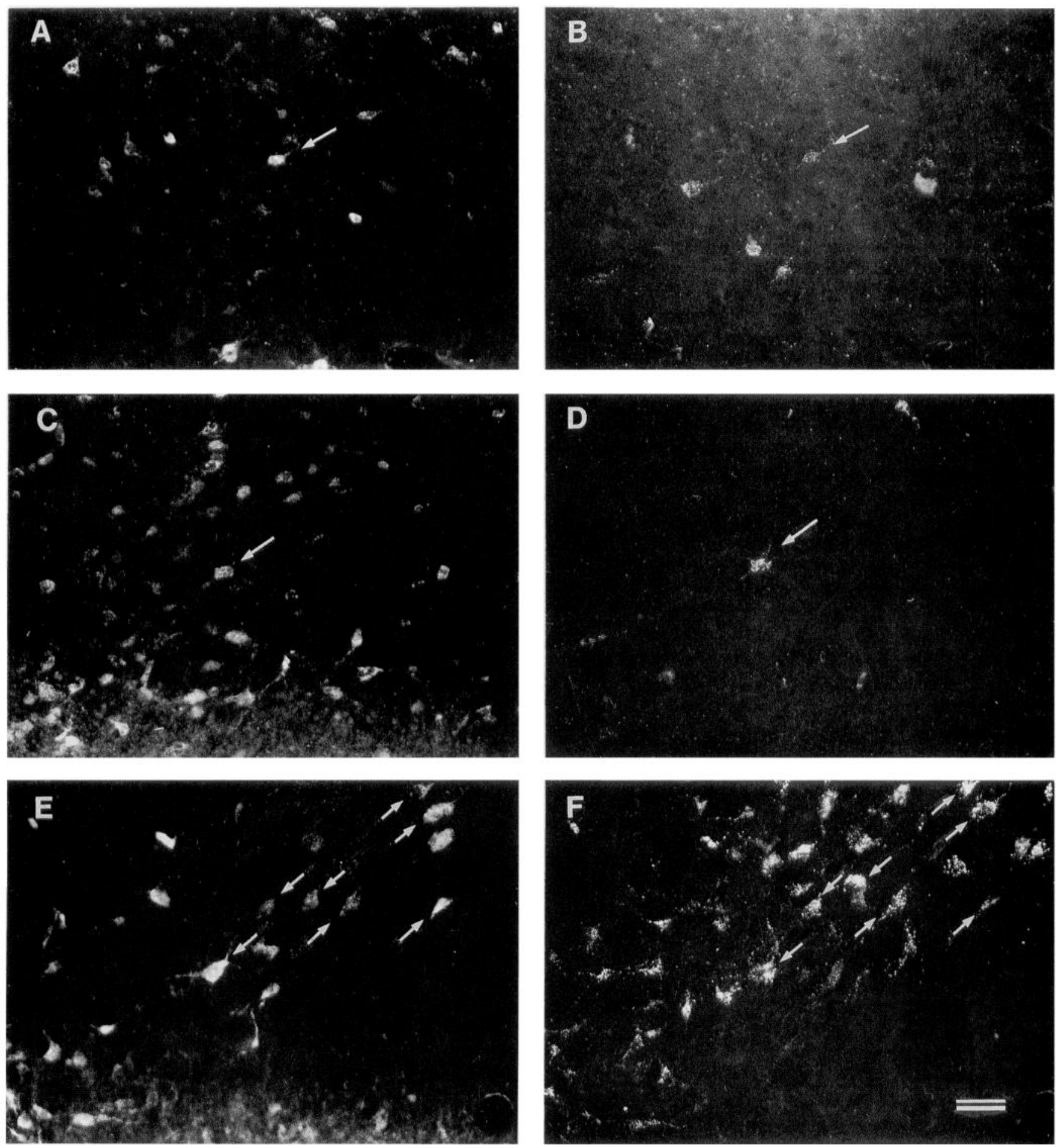

Figure 9. Photomicrographs of retrogradely labeled cells in the dorsal raphe $(A, B)$ (case OR4), mesencephalic reticular formation $(C, D)$ (case OR2), and fastigial nucleus $(E, F)$ (case OR4) from the injections of FG into the thalamus (left column) and R-Mb into the NTS (right column), respectively. Dually labeled cells are indicated with arrows. Scale bar, $50 \mu \mathrm{m}$. 

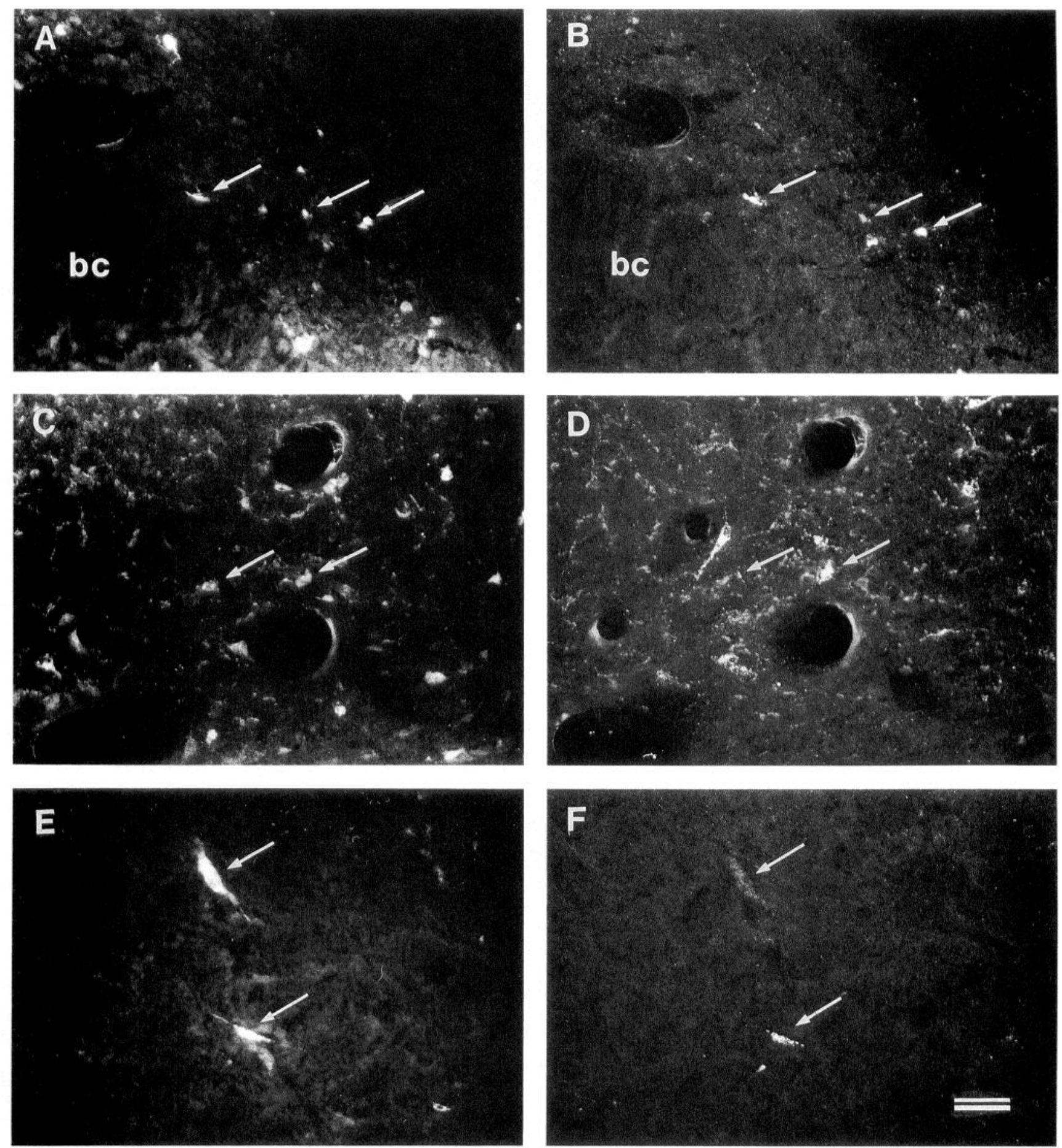

Figure 10. Photomicrographs of retrogradely labeled cells in the lateral parabrachial nucleus $(A, B)$ (case OR4), the laterodorsal tegmental nucleus $(C, D)$ (case OR2), and the A5 area $(E, F)$ (case OR5) from injections of FG into the thalamus (left column) and R-Mb into the NTS (right column). Dually labeled cells are indicated with arrows. $b c$, brachium conjunctivum. Scale bar, $50 \mu \mathrm{m}$. 

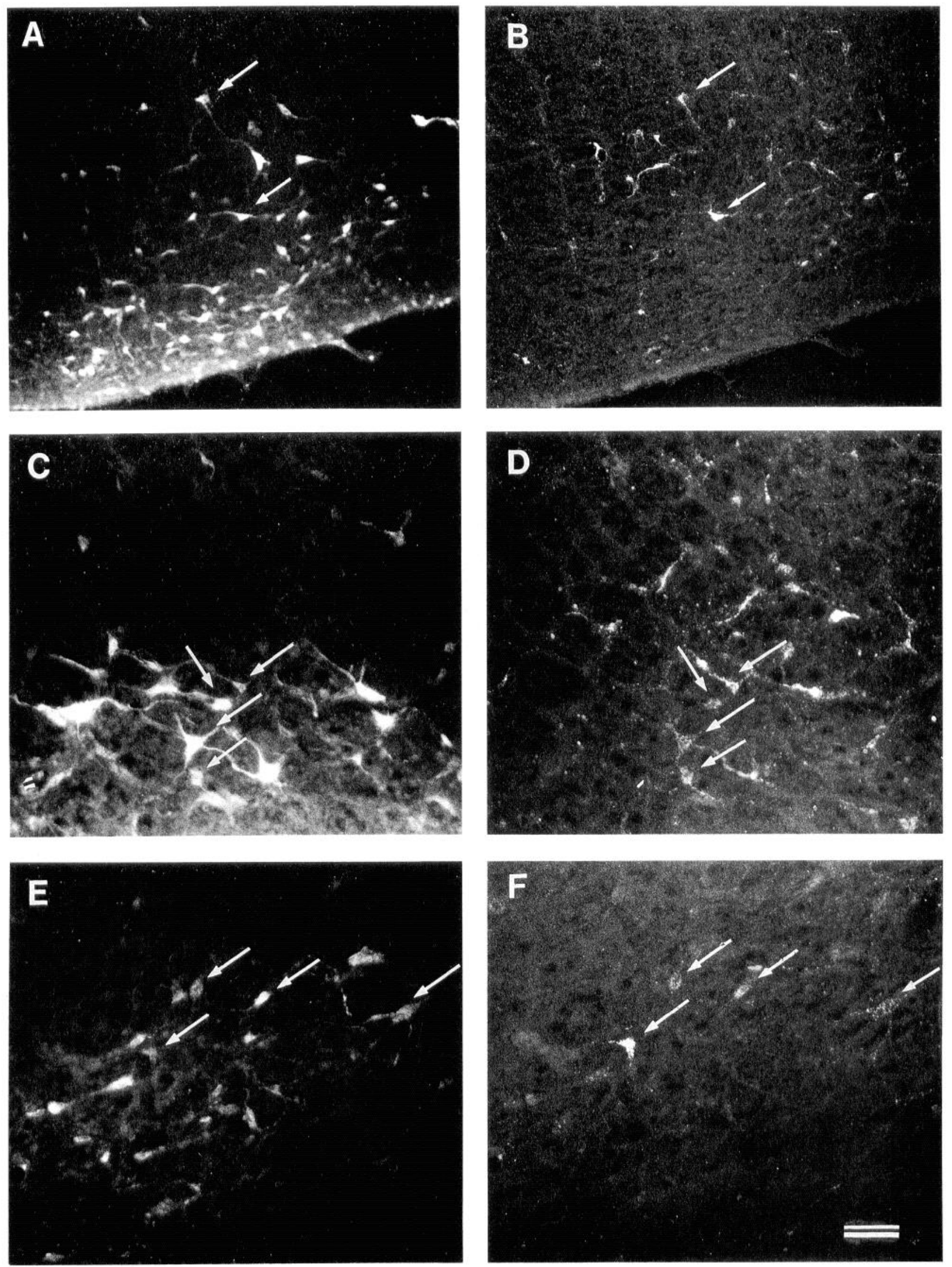

Figure 11. Photomicrographs of retrogradely labeled cells in the rostral ventrolateral reticular nucleus $(A, B)$ (case OR4), the retroambigual area $(C, D)$ (case OR4), and the parapyramidal area $(E, F)$ (case OR5) from injections of FG into the thalamus (left column) and R-Mb into the NTS (right column). Dually labeled cells are indicated with arrows. Scale bar: $100 \mu \mathrm{m}$ for $A$ and $B, 50 \mu \mathrm{m}$ for $C-F$. 


\section{Functional considerations}

Of functional importance are the neural networks through which afferents from the internal and external milieux are gated by the CNS to modify selectively forebrain and somatovisceral reflex function. The precise functions of each of the collateral projections cannot be determined from the structural data. It is conceivable that collaterals may serve as integrators by distributing signals to nuclei subserving functionally differentiated components of afferent processing and integrative reflex control. Stimuli leading to the defense/arousal response (pain, e.g.), may be distributed, in part, by the branched afferents identified here.

The significance of multiple sources of afferents to the dorsal thalamus and NTS-X arising from different levels of the neuraxis may be related to the functional specificity of each source of afferent projection. Hierarchical levels of sensory processing have been ascribed to each of the major divisions of the nervous system (for reviews, see Gebhart, 1986; Ruggiero et al., 1994).

Collaterals from the medullary reticular formation stem from an area of the lateral tegmental field (LTF) long recognized as a sensory convergent center (Valverde, 1961). The LTF has been implicated as an outlet for lower brainstem reflex circuits involved in generating sympathetic nerve discharge, respiratory patterning, and somatovisceral reflex integration (Gebber and Barman, 1985; Reis and Ruggiero, 1991; Yates, 1992). One circumscribed source of collaterals from LTF was observed in the rostral ventrolateral medulla (rVLM) - a region of reticular formation integrated in bidirectional feedback circuits with the NTS-X (cardiovascular, Ciriello and Caverson, 1986; respiratory, Ellenberger and Feldman, 1990). This observation is intriguing in view of the importance of this region in afferent convergence and somatoautonomic reflex control. Reflexes ascribed to the rVLM include nociceptive and exercise pressor responses (Iwamoto et al., 1982; Stornetta et al., 1989), the baroreceptor reflex (Granata et al., 1985), and chemoreceptor reflex control of autonomic and respiratory motor neurons (Bennaroch et al., 1986; Millhorn and Eldridge, 1986; Ruggiero et al., 1991). Interestingly, prethalamic afferents arise from sites in rVLM implicaled in oxygen-conserving reflexes such as the cerebral ischemic response (Kumada et al., 1979; Guyenet and Brown, 1986) or the global cerebrovascular vasodilation to hypoxia (Underwood et al., 1986).

Collaterals to the MIT and NTS-X also derive from the laterodorsal tegmental nucleus in the mesopontine tegmentum. The functional significance of these collaterals is unknown. Perhaps related is evidence that this region, together with the pedunculopontine tegmental nucleus, has been implicated in ascending cholinergic regulation of sensory gating functions, attributed to the $\mathrm{Ch} 6$ and $\mathrm{Ch} 5$ groups, respectively (Steriade and Llinás, 1988). The Ch5 and Ch6 areas also project to the basal ganglia and are thought to play a key integrative role in extrapyramidal motor function (Woolf and Butcher, 1986; Beninato and Spencer, 1987; Rye et al., 1987). The NTS-X and rVLM are enriched in cholinergic afferents involved in central autonomic regulation (Spencer and Talman, 1986; Giuliano et al., 1989; Ruggiero et al., 1990). Collateral projections to the NTS-X and, conceivably, the aforementioned visceral relay center in ventrolateral medulla (Yasui et al., 1991) predict that neurons in the mesopontine tegmentum may also influence visceral reflex function and integrate these two levels of afferent processing. Evidence of collaterals from the periaqueductal gray may be related to functions ascribed to this region, including nociceptive control (Basbaum and Fields, 1984; Pechura and
Liu, 1986) and an outlet for behavioral expression (Magoun et al., 1937; Bandler, 1982).

Forebrain afferents derive from areas of cerebral cortex and subcortical telencephalon implicated in affective processing of multimodal afferents (LeDoux, 1987, for review).

Prominent sources of collaterals are the insular and infralimbic areas of cerebral cortex. Functions ascribed to these cortical areas are related to their role in conveying olfactory, gustatory, and general visceral signals from the periphery, by way of specific sensory thalamic relay neurons or other sensory relay nuclei in brainstem, for example, the parabrachial complex (Cechetto and Saper, 1987; Allen et al., 1991). The insular cortex is thought to couple behavioral and autonomic components of emotional expression through connections with the infralimbic prefrontal cortex, dorsal thalamus, hypothalamus, and amygdala (Krushel and van der Kooy, 1988).

Collaterals to the dorsal thalamus and NTS-X also arise from areas of the amygdala or bed nuclei of the stria terminalis implicated in autonomic or behavioral components of conditioned defense or fear responses. The amygdala is thought to lie in a pivotal position by serving as a convergence center for complex multimodal affective affercnt proccssing and an outlet for behavioral expression by the telencephalon. Amygdaloid neurons appear to trigger "fixed-action" patterns of hehavior by way of anatomically divergent pathways that engage somatomotor, autonomic, neuroendocrine, and affective components of behavioral responses. It is conceivable that these branched afferents may contribute to some observed effects attributed to the amygdala or its efferent pathways. Examples include visceral responses to emotionally charged stimuli or other of the experiential phenomena associated with temporal lobe epilepsy (Hilton and Zbrozyna, 1963; Igic et al., 1970; Smith et al., 1980; Bandler, 1982; Gloor et al., 1982; Bandler and McCulloch, 1984; Mondlock and Davis, 1985; Iwata et al., 1986a,b). The lateral hypothalamus, another source of collaterals, is a mandatory diencephalic relay for cortical-sympathetic responsivity (Cechetto and Chen, 1990).

In conclusion, the collateral projections identificd in this study may coordinate alterations in electrocortical activity and visceral reflex excitability associated with recurring phases of the sleep-wake cycle or modes of behavioral expression.

$\begin{array}{ll}\text { Appendix } \\ \text { Abbreviations used in figures } \\ \text { ac } & \text { anterior commissure } \\ \text { aca } & \text { anterior cingulate area } \\ \text { acb } & \text { nucleus accumbens } \\ \text { aha } & \text { amygdalohippocampal area } \\ \text { aid } & \text { agranular insular area, dorsal part } \\ \text { aip } & \text { agranular insular area, posterior part } \\ \text { aiv } & \text { agranular insular area, ventral part } \\ \text { ap } & \text { area postrema } \\ \text { apo } & \text { anterior preoptic nuclcus of Loo } \\ \text { arc } & \text { arcuate nucleus } \\ \text { A5 } & \text { A5 noradrenergic cell group } \\ \text { bc } & \text { brachium conjunctivum } \\ \text { bl } & \text { basolateral amygdaloid nucleus } \\ \text { ca } & \text { central amygdaloid nucleus } \\ \text { ci } & \text { inferior colliculus } \\ \text { cli } & \text { caudal linear nucleus of raphe } \\ \text { cm } & \text { central medial thalamic nucleus } \\ \text { cp } & \text { cerebral peduncle } \\ \text { c-p } & \text { caudate-putamen }\end{array}$


cvl caudal ventrolateral reticular nucleus

dg

dmh dorsomedial hypothalamic nucleus

dtc dorsal tegmental nucleus, central (compact) division

en endopiriform nucleus

fr fasciculus retroflexus

g genu of the facial nerve

gp globus pallidus

ila infralimbic area

hb

I

III

imd

ip

l

la

ld

lh

lot

Ir

Isi

rht

rsa

rvl

$\mathrm{sm}$

snr

medial and lateral habenular nuclei

lingula

oculomotor nucleus

intermediodorsal thalamic nucleus

interpeduncular nucleus

lateral parabrachial nucleus

lateral amygdaloid nucleus

laterodorsal tegmental nucleus

lateral hypothalamic area

lateral olfactory tract

lateral reticular nucleus

lateral septal nucleus, intermediate part

medial parabrachial nucleus

medial amygdaloid nucleus

mediodorsal thalamic nucleus

medial geniculate complex

medial lemniscus

magnocellular preoptic nucleus

medial preoptic nucleus

mesencephalic reticular formation

mammillothalamic tract

medial vestibular nucleus

nucleus ambiguus (compact formation)

nucleus of the diagonal band

nucleus of the solitary tract

olfactory tubercle

periaqueductal gray

paracentral thalamic nucleus

parafascicular thalamic nucleus

pontine gray

paragigantocellular reticular nucleus

posterior hypothalamic area

piriform cortex

posterior thalamic nucleus

pedunculopontine tegmental nucleus

perirhinal cortex

paraventricular hypothalamic nucleus

paraventricular thalamic nucleus

dorsal raphe nucleus

rhinal fissure

rhomboid thalamic nucleus

retrosplenial agranular cortex

rostral ventrolateral reticular nucleus

stria medullaris

substantia nigra, pars reticulata

supcrior olivary complex

supramammillary nucleus

superior vestibular nucleus

spinal trigeminal nucleus

facial nucleus

facial nerve

motor nucleus of the trigeminal nerve

ventromedial hypothalamic nucleus

principal sensory nucleus of the trigeminal nerve

ventral tegmental nucleus

dorsal motor nucleus of the vagus

hypoglossal nucleus

zona incerta

cerebral cortex, layers I-VI
Asanuma C (1992) Noradrenergic innervation of the thalamic reticular nucleus: a light and electron microscopic immunohistochemical study in rats. J Comp Neurol 319:299-311.

Bandler RJ (1982) Induction of "rage" following microinjections of glutamate into midbrain but not hypothalamus of cats. Neurosci Lett 30:183-188.

Bandler RJ, McCulloch T (1984) Afferents to a midbrain periaqueductal grey region involved in the "defense reaction" in the cat as revealed by horseradish peroxidase. II. The diencephalon. Behav Brain Res 13:279-285.

Basbaum AI, Fields HL (1984) Endogenous pain control systems: brainstem spinal pathways and endorphin circuitry. Annu Rev Neurosci 7:308-338.

Benarroch EE, Granata AR, Ruggiero DA, Park DH, Reis DJ (1986) Neurons of the $\mathrm{Cl}$ area mediate cardiovascular responses initiated from the ventral medullary surfacc. Am J Physiol 250:R932-R945.

Beninato M, Spencer RF (1987) A cholinergic projection to the rat substantia nigra from the pedunculopontine tegmental nucleus. Brain Res 412:169-174.

Berendse HW, Groenewegen HJ (1991) Restricted cortical termination fields of the midline and intralaminar thalamic nuclei in the rat. Neuroscience 42:73-102.

Berk ML, Finkelstein JA (1982) Efferent connections of the lateral hypothalamic area of the rat: an autoradiographic investigation. Brain Res Bull 8:511-526.

Cechetto DF, Chen SJ (1990) Subcortical sites mediating sympathetic responses from the insular cortex in the rat. Am J Physiol 258:R245R255.

Cechetto DF, Saper CB (1987) Evidence for a viscerotopic sensory representation in the cortex and thalamus in the rat. J Comp Neurol 262:27-45.

Ciriello J, Caverson MM (1986) Bidirectional cardiovascular connections between ventrolateral medulla and nucleus of the solitary tract. Brain Res 367:273-281.

Cornwall J, Phillipson OT (1988) Afferent projections to the dorsal thalamus of the rat as shown by retrograde lectin transport. II. The midline nuclei. Brain Res Bull 21:147-161.

Eberhart JA, Morrell JI, Krieger MS, Pfaff DW (1985) An autoradiographic study of projections ascending from the midbrain central gray, and from the region lateral to it. J Comp Neurol 241:285-310.

Ellenberger HH, Feldman JL (1990) Subnuclear organization of the lateral tegmental field of the rat. I: nucleus ambiguus and ventral respiratory group. J Comp Neurol 294:202-211.

Gebber GL, Barman SM (1985) Lateral tegmental field neurons of cat medulla: a potential source of basal sympathetic nerve discharge. $J$ Neurophysiol 54:1498-1512.

Gebhart GF (1986) Modulatory effects of descending systems on spinal dorsal horn neurons. In: Spinal afferent processing (Yaksh TL, ed), pp 391-416. New York: Plenum.

Giuliano R, Ruggiero DA, Morrison S, Ernsberger P, Reis DJ (1989) Cholinergic regulation of arterial pressure by the $\mathrm{Cl}$ area of the rostral ventrolateral medulla. J Neurosci 9:923-942.

Gloor P, Olivier A, Quesney LF, Andermann F, Horowitz S (1982) The role of the limbic system in experiential phenomena of temporal lobe epilepsy. Ann Neurol 12:129-144.

Granata AR, Ruggiero DA, Park DH, Joh TH, Reis DJ (1985) Brain stem area with $\mathrm{Cl}$ epinephrine neurons mediates baroreflex vasodepressor responses. Am J Physiol 248:H547-H567.

Guyenet PG, Brown DL (1986) Unit activity in nucleus paragigantocellularis lateralis during cerebral ischemia in the rat. Brain Res 364:301-314.

Herkenham M (1986) New perspectives on the organization and evolution of nonspecific thalamocortical projections. In: Cerebral cortex, Vol 5 (Jones EG, Peters A, eds), pp 403-445. New York: Plenum.

Hilton SM, Zbrozyna AW (1963) Amygdaloid region for defense reactions and efferent pathway to the brain stem. J Physiol (Lond) 165: 160-173.

Holstege G, Meiners L, Tan K (1985) Projections of the bed nucleus of the stria terminalis to the mesencephalon, pons, and medulla oblongata in the cat. Exp Brain Res 58:370-391.

Hopkins DA, Holstege G (1978) Amygdaloid projections to the mesencephalon, pons and medulla oblongata in the cat. Exp Brain Res 32:529-547.

Igic R, Stern P, Basagio E (1970) Changes in emotional behavior after application of cholinesterase inhibition in the septal and amygdala region. Neuropharmacology 9:73-75.
Allen GV, Saper CB, Hurley KM, Cechetto DF (1991) Organization of visceral and limbic connections in the insular cortex of the rat. $J$

\section{Comp Neurol 311:1-16. \\ References}

\author{
region. Neuropharmacology $9: 73-75$.
}


Iwamoto GA, Kaufman MP, Botterman BR, Mitchell JH (1982) Effects of lateral reticular lesions on the exercise pressor reflex in cats. Circ Res 51:400-403.

Iwata J, LeDoux JE, Reis DJ (1986a) Destruction of intrinsic neurons in the lateral hypothalamus disrupts cardiovascular but not behavioral conditional responses. Brain Res 368:161-166.

Iwata J, LeDoux JE, Meeley MP, Arneric S, Reis DJ (1986b) Intrinsic neurons in the amygdaloid field projected to the medial geniculate body mediate emotional responses conditioned to acoustic stimuli. Brain Res 383:195-214.

Jackson JH, Stewart P (1899) Epileptic attack with a warning of a crude sensation of smell and with intellectual aura (dreamy state) in a patient who had symptoms pointing to gross organic disease of the right temporo-sphenoidal lobe. Brain 22:534-549.

Jones BE (1989) Basic mechanisms of sleep-wake states. In: Principles and practice of sleep medicine (Kryger MH, Roth T, Dement WC, eds), pp 121-138. Philadelphia: Saunders.

Jones BE, Cuello AC (1989) Afferents to the basal forebrain cholinergic cell area from pontomesencephalic-catecholamine, serotonin, and acetylcholine-neurons. Neuroscience 31:37-61.

Jones BE, Yang T-Z (1985) The efferent projections from the reticular formation and the locus coeruleus studied by anterograde and retrograde axonal transport in the rat. J Comp Neurol 242:56-92.

Jones EG (1985) The thalamus. New York: Plenum.

Jordan D (1990) Autonomic changes in affective behavior. In: Central regulation of autonomic functions (Loewy AD, Spyer KM, eds), pp 367-386. New York: Oxford UP.

Ju G, Swanson LW (1989) Studies on the cellular architecture of the bed nuclei of the stria terminalis in the rat: I. Cytoarchitecture. J Comp Neurol 280:587-602.

Krushel AA, van der Kooy D (1988) Visceral cortex: integration of the mucosal senses with limbic information in the rat agranular insular cortex. J Comp Neurol 270:39-54.

Kumada M, Dampney RAL, Reis DJ (1979) Profound hypotension and abolition of the vasomotor component of the cerebral ischemic response produced by restricted lesions of medulla oblongata in rabbit: so-called tonic vasomotor center. Circ Res 45:63-70.

LeDoux JE (1986) Sensory systems and emotion: a model of affective processing. Integrat Psychiatry 4:237-248.

LeDoux JE (1987) Emotion. In: Handbook of physiology - the nervous system V (Plum F, ed), pp 419-459. Bethesda, MD: American Physiological Society.

Loewy AD, Spyer KM (1990) Vagal preganglionic neurons. In: Central regulation of autonomic functions (Loewy AD, Spyer KM, eds), pp 68-87. New York: Oxford UP.

Luiten PGM, ter Horst GJ, Karst H, Steffens AB (1985) The course of paraventricular hypothalamic efferents to autonomic structures in medulla and spinal cord. Brain Res 329:374-378.

Magoun HW, Atlas D, Ingersoll EH, Ranson SW (1937) Associated facial, vocal and respiratory components of emotional expression: an experimental study. J Neurol Psychopathol 17:241-255.

Millhorn DE, Eldridge FL (1986) Role of ventrolateral medulla in regulation of respiratory and cardiovascular systems. J Appl Physiol 61:1249-1263.

Mondlock JM, Davis M (1985) The role of various amygdala projection areas (bed nucleus of stria terminalis, rostral lateral hypothalamus, substantia nigra) in fear-enhanced acoustic startle. Soc Neurosci Abstr 11:331.

Otake K, Anwar M, Reis DJ, Nakamura Y, Ruggiero DA (1993) Structural basis for visceral sensory and midline thalamic integration. Soc Neurosci Abstr 19:434.

Parmeggani PL, Morrison AR (1990) Alterations in autonomic functions during sleep. In: Central regulation of autonomic functions (Loewy AD, Spyer KM, eds), pp 367-386. New York: Oxford UP.

Paxinos G, Watson C (1986) The rat brain in stereotaxic coordinates, 2d ed. Sydney: Academic.

Pechura CM, Liu RP (1986) Spinal neurons which project to the periaqueductal gray and the medullary reticular formation via axon collaterals: a double-label fluorescence study in the rat. Brain Res 374: 357-361.

Pickering TG (1990) Diurnal rhythms and other sources of blood pressure variability in normal and hypertensive subjects. In: Hypertension: pathophysiology, diagnosis, and management (Laragh $\mathrm{JH}$, Brenner BM, eds), pp 1397-1405. New York: Raven.
Plum F, Posner JB (1980) The diagnosis of stupor and coma, 3d ed. Philadelphia: Davis.

Purpura DP (1970) Operations and processes in thalamic and synaptically related neural subsystems. In: The neuroscience: second study program (Schmitt FO, ed), pp 458-470. New York: Rockefeller UP

Reis DJ, Ruggiero DA (1991) The bed nucleus of the transtegmental tract: a major autonomic integration center of the medulla oblongata. Soc Neurosci Abstr 16:11.

Ricardo JA, Koh ET (1978) Anatomical evidence of direct projections from the nucleus of the solitary tract to the hypothalamus, amygdala, and other forebrain structures in the rat. Brain Res 153:1-26.

Rinaman L, Card JP, Schwaber JS, Miselis RR (1989) Ultrastructural demonstration of a gastric monosynaptic vagal circuit in the nucleus of the solitary tract in rat. J Neurosci 9:1985-1996.

Ross CA, Ruggiero DA, Reis DJ (1981) Afferent projections to cardiovascular portions of the nucleus tractus solitarii in the rat. Brain Res 223:402-408.

Ruggiero DA, Mraovitch S, Granara AR, Anwar M, Reis DJ (1987) A role of insular cortex in cardiovascular function. J Comp Neurol 257:189-207.

Ruggiero DA, Cravo SL, Arango V, Reis DJ (1989) Central control of the circulation by rostral ventrolateral reticular nucleus: anatomical substrates. Prog Brain Res 81:49-79.

Ruggiero DA, Giuliano R, Anwar M, Stornetta R, Reis DJ (1990) Anatomical substrates of cholinergic-autonomic regulation in the rat. J Comp Neurol 292:1-53.

Ruggicro DA, Gomez RE, Cravo SL, Mtui E, Anwar M, Reis DJ (1991) The rostral ventrolateral medulla: anatomical substrates of cardiopulmonary integration. In: Cardiorespiratory and motor coordination (Koepchen H-P, Huopaniemi T, eds), pp 89-102. New York: Springer.

Ruggiero DA, Pickel VM, Milner TA, Anwar M, Otake K, Mtui EP, Park D (1994) Viscerosensory processing in nucleus tractus solitarii: structural and neurochemical substrates. In: Nucleus of the solitary tract (Barraco RA, ed), pp 3-34. Boca Raton, FL: CRC.

Rye DB, Saper CB, Lee HJ, Wainer BH (1987) Pedunculopontine tegmental nucleus of the rat; cytoarchitecture, cytochemistry, and some extrapyramidal connections of the mesopontine tegmentum. J Comp Neurol 259:483-528.

Saper CB, Loewy AD (1980) Efferent connections of the parabrachial nucleus in the rat. Brain Res 197:291-317.

Saper CB, Swanson LW, Cowan WM (1979) An autoradiographic study of the efferent connections of the lateral hypothalamic area in the rat. J Comp Neurol 183:669-707.

Schwaber JS, Kapp BS, Higgins GA, Rapp PR (1982) Amygdaloid and basal forebrain direct connections with nucleus of the solitary tract and the dorsal motor nucleus. J Neurosci 2:1424-1438.

Sesack SR, Deutch AY, Roth RH, Bunney BS (1989) Topographical organization of the efferent projections of the medial prefrontal cortex in the rat: an anterograde tract-tracing study with Phaseolus vulgaris leucoagglutinin. J Comp Neurol 290:213-242.

Shute CCD, Lewis PR (1963) Cholinesterase-containing systems of the brain of the rat. Nature 199:1160-1164.

Shute CCD, Lewis PR (1967) The ascending cholinergic reticular system: ncocortical, olfactory and subcortical projections. Brain 90:497520.

Smith OA, Astley CA, DeVito JL, Stein JM, Walsh RE (1980) Functional hypothalamic control of the cardiovascular responses accompanying emotional behavior. Fed Proc 29:2487-2494.

Spencer SE, Talman WT (1986) Central modulation of gastric pressure by substance P: a comparison with glutamate and acetylcholine. Brain Res 385:371-374.

Starzl TE, Magoun HW (1951) Organization of the diffuse thalamic projection system. J Neurophysiol 14:133-146.

Steriade M, Llinás RR (1988) The functional states of the thalamus and the associated neuronal interplay. Physiol Rev 68:649-742.

Steriade M, Jones EG, Llinás RR (1990) Thalamic oscillations and signaling. New York: Wiley.

Stornetta R, Morrison SL, Ruggicro DA, Reis DJ (1989) Neurons in the rostral ventrolateral medulla mediate the somatic pressor reflex. Am J Physiol 25:R448-R462.

ter Horst GJ, Luiten PGM, Kuipers F (1984) Descending pathways from hypothalamus to dorsal motor vagus and ambiguus nuclei in the rat. J Autonom Nerv Syst 11:59-75. 
Underwood MD, Iadecola C, Reis DJ (1986) Bilateral lesion of the $\mathrm{Cl}$ area of the rostral ventrolateral medulla globally impairs the ccrebrovascular response to hypoxia. Soc Neurosci Abstr 12:1320.

Valverde F (1961) Reticular formation of the pons and medulla oblongata. A Golgi study. J Comp Neurol 116:71-99.

van der Kooy D, Koda LY, McGinty JF, Gerfen CR, Bloom FE (1984)

The organization of projections from the cortex, amygdala, and hypothalamus to the nucleus of the solitary tract in rat. J Comp Neurol $224: 1-24$.

Vincent SR, Satoh K, Armstrong DM, Panule P, Vale W, Fibiger HC (1986) Neuropeptides and NADPH-diaphorase activity in the ascending cholinergic reticular system of the rat. Neuroscience 17:167182.
Woolf NJ, Butcher LL (1986) Cholinergic systems in the rat brain III. Projections from the pedunculopontine tegmentum to the thalamus, tectum, basal ganglia, and basal forebrain. Brain Res Bull 16:603637.

Yasui Y, Cechetto DF, Saper CB (1990) Evidence for cholinergic projection from the pedunculopontine tegmental nucleus to the rostral ventrolateral medulla in the rat. Brain Res 517:19-24.

Yates BJ (1992) Vestibular influences on the sympathetic nervous system. Brain Res Rev 17:51-59.

Yingling CD, Skinner JE (1976) Selective regulation of thalamic sensory relay nuclei by nucleus reticularis thalami. Electoencephalogr Clin Neurophysiol 41:476-482. 